\begin{tabular}{ll}
\hline & Jurnal Sains Materi Indonesia \\
Homepage: http://jusami.batan.go.id & $\begin{array}{l}\text { Akreditasi LIPI } \\
\text { No.: 602/AU3/P2MI-LIPI/03/2015 } \\
\text { Tanggal 15 April 2015 } \\
\text { ISSN : 1411-1098 }\end{array}$ \\
\hline
\end{tabular}

\title{
SIMULASI DINAMIKA MOLEKULAR REAKTIF PROSES AMORFISASI SILIKON KRISTAL
}

\author{
Mauludi Ariesto Pamungkas dan Rendra Widiyatmoko \\ Jurusan Fisika, FMIPA - Universitas Brawijaya \\ Jl.Veteran 2, Malang 65145 \\ E-mail: m_ariesto@ub.ac.id
}

Diterima: 6 Januari 2017 Diperbaiki: 6 April $2017 \quad$ Disetujui: 10 April 2017

\begin{abstract}
ABSTRAK
SIMULASI DINAMIKA MOLEKULAR REAKTIF PROSES AMORFISASI SILIKON KRISTAL. Silikon kristal dan silicon amorf adalah material utama yang digunakan untuk bahan solar sel. Silikon amorf lebih mudah dibuat dan lebih murah dibandingkan silikon kristal namun efisiensi silikon amorf masih lebih rendah dibanding silikon kristal. Untuk meningkatkan sifat listrik dari silikon amorf diperlukan pengetahuan strukturmikro silikon amorf yang terbentuk dari amorfisasi silikon kristal. Oleh karena itu dilakukan simulasi dinamika molekuler untuk meneliti proses amorfisasi silikon kristal. Proses amorfisasi dilakukan dengan cara yang menyerupai proses dalam eksperimen, yaitu pemanasan sampai silikon kristal mencair kemudian dilanjutkan dengan pendinginan yang cepat sehingga tidak cukup waktu untuk atom-atomnya membentuk struktur yang teratur. Setelah beberapa suhu dan kecepatan pendinginan dicoba, didapati bahwa dengan pemanasan sampai $3500 \mathrm{~K}$ dan dengan laju pendinginan $10^{14} \mathrm{~K} / \mathrm{s}$ silikon amorf terbentuk. Pada suhu yang terlalu tinggi, sistem menjadi rusak, sedangkan pada suhu yang terlalu rendah tidak terjadi perubahan fase. Proses amorfisasi disertai dengan meningkatnya panjang rata-rata ikatan dari ikatan 4-4 fold, 4-5 fold, dan 5-5 fold secara berurutan. Selain itu, didapati bahwa ikatan 5-fold memberikan kontribusi paling besar dalam membentuk puncak sudut $60^{\circ}$.
\end{abstract}

Kata kunci: Silikon amorf, Silikon kristal, Dinamika molekular

\begin{abstract}
REACTIVE MOLECULAR DYNAMICS SIMULATION OF AMORPHIZATION PROCESS OF CRYSTALLINE SILICON. Crystalline silicon and amorphous silicon are main material of solar cell. Amorphous silicon is more easily formed and cheaper than crystalline silicon. In order to enhance the electronic property of amorphous silicon, knowledge of its microstructure, which is formed from amorphization of crystalline silicon, is a must. Molecular dynamic simulation with reactive force field has been performed to investigate amorphization process of crystalline silicon. Amorphization process was performed to mimic real process in experimental work by heating crystalline silicon until it was melted then followed by quenching. After trial with various temperatures, we found that by heating up to $3500 \mathrm{~K}$ and employing a cooling rate of $1014 \mathrm{~K} / \mathrm{s}$, amorphous silicon can be formed. Heating with higher temperature will collapse the system. While heating with lower temperature does not lead to phase transformation. Amorphization process is accompanied by an increase of average bond length of 4-4 fold, 4-5 fold, and 5-5 fold. In addition, 5-fold bond gives the biggest contribution in forming peak at $60 p$.
\end{abstract}

Keywords: Amorphous silicon, Crystalline Silicon, Molecular dynamics

\section{PENDAHULUAN}

Material yang banyak digunakan sebagai konversi energi matahari (sel surya, photovoltaic) adalah silikon kristal, c-Si [1]. Pada tahun 1974 di laboratorium Radio Coorporation of America (RCA), berhasil dibuat sel solar dari lapisan tipis silikon amorf (a-Si:H) dengan metode lucutan pijar (glow discharge). Pada tahun 1976, berhasil dibuat sel surya a-Si:H dengan efisiensi konversi energi matahari sebesar 2\%-3\%. Saat ini efisiensinya sudah meningkat sekitar $11,4 \%$ untuk sel surya single junction dan 16,3\% sel surya triple junction [2]. Sampai 
saat ini silikon amorf selalu dihidrogenisasi untuk mengurangi electron tidak berpasangan (dangling bond). Dangling bond ini menyebabkan penurunan sifat elektronik dan optik dari silikon amorf [3]. Namun demikian, dengan penyinaran yang lama, hydrogen justru dipercaya menimbulkan dangling bond baru yang berakibat turunnya kinerja dari sel surya[4]. Karena itu banyak sekali penelitian teoritis dilakukan untuk mencari tahu mekanisme sebenarnya dari efek positif maupun negatif dari Hidrogen karena sampai saat ini mekanisme detail nya belum bisa disepakati oleh para peneliti $[5,6]$. Hal ini juga tidak terlepas dari pengetahuan bagaimana ikatan-ikatan atomik terbentuk saat terjadi hidrogenisasi silikon amorf.

Penulis juga meneliti proses hidrogenisasi dari silikon amorf dan melaporkannya pada artikel terpisah [7]. Pada artikel ini penulis memaparkan proses yang harus dilakukan sebelumnya, yaitu proses amorfisasi silikon Kristal. Ketidakteraturan yang memunculkan cacat structural pada amorf dipercaya sebagai sumber dari degradasi kinerjanya [8,9]. Di antara cacat struktural pada silikon amorf adalah adanya atom silikon dengan 3 ikatan dan 5 ikatan, sedangkan pada silikon kristal semua atom memiliki 4 ikatan dengan atom tetangga terdekat $[10,11]$.

Berbeda dengan kondisi pada eksperimen, di mana hasil deposisi adalah silikon amorf, pada simulasi kita harus mulai dengan silikon kristal, kemudian diamorfisasi dengan pemanasan pada suhu tinggi dan dilanjutkan dengan pendinginan secara cepat.

Simulasi dinamika molekuler merupakan suatu teknik komputasi yang merepresentasikan interaksi atom-atom berdasarkan fungsi waktu dengan menyelesaikan persamaan geraknya. Sebelumnya, Byeoung June Min [12] dan Ishimaru [13] dan Jason et.al [14] dan Treacy et.al [15] melakukan simulasi dinamika molekuler namun demikian mereka tidak menggunakan potensial reaktif sehingga tidak bisa memperlihatkan dinamika perubahan jumlah tetangga terdekat dan transfer muatan.

Walaupun untuk proses amorfisasi tidak dibutuhkan potensial yang bisa menggambarkan proses transfer muatan, namun untuk fungsionalisasi silikon amorf yang terbentuk, seperti hidrogensisasi dan oksidasi maka sangat dibutuhkan potensial yang bisa menggambarkan transfer muatan. Maka untuk keberlanjutan, pada penelitian ini digunakan potensial reaktif (reactive force field) yang dibuat oleh grup Van Duin untuk silikon dan silikon oksida [16] yang bisa menggambarkan proses pemutusan dan pembentukan ikatan serta proses transfer muatan.

Dengan menggunakan potensial reaktif, informasi terkait dinamika perubahan ikatan dan perubahan jumlah tetangga terdekat dari tiap atom silikon dapat diungkap secara lebih lengkap dan jelas dibandingkan simulasi amorfisasi silikon yang telah dilakukan peneliti-peneliti sebelumnya.
Karena itu penelitian ini bertujuan untuk bisa mengungkap lebih dalam ikatan-ikatan yang terbentuk selama dan setelah proses amorfisasi. Penelitian ini berhasil menggali informasi terkait panjang rata-rata ikatan, distribusi jumlah ikatan, perubahan ikatan yang terjadi dan sudut ikatan rata-rata yang terbentuk

\section{METODE PERCOBAAN}

Untuk mengubah dari fase kristal menjadi amorf dilakukan dengan pemanasan sampai melwati suhu lelehnya kemudian dilanjutkan dengan pendinginan cepat sehingga atom-atom tidak sempat mengatur diri dan terjebak dalam ketidak teraturan. Karena itu dalam simulasi ini, proses amorfisasi dilakukan dengan memanaskan struktur kristal silikon hingga mencapai titik leburnya (melting) kemudian melakukan pendingan (quenching) dengan laju pendinginan (cooling rate) yang tinggi (1012-1015K/s) hingga mencapai suhu ruangan. Proses pemanasan (melting) dilakukan dengan menerapkan velocity rescaling hingga sistem mencapai suhu $3500 \mathrm{~K}$, kemudian melakukan proses pendinginan dengan menerapkan ensembel NVT dengan laju pendinginan $1014 \mathrm{~K} / \mathrm{s}$ hingga mencapai suhu 300K.

Simulasi ini menggunakan Reactive Force Field (ReaxFF) yang dibuat oleh grup Van Duin yang diimplementasikan pada perangkat lunak dinamika molekuler LAMMPS yang bisa mensimulasi berbagai bentuk dan kondisi sistem material [17]. Sebagaimana telah dikemukakan pada bagian pendahuluan, dipilihnya ReaxFF dikarenakan kemampuannya menggambarkan proses pembentukan dan pemutusan ikatan serta transfer muatan. Di samping itu komponen-komponen Fungsi potensial ini juga lengkap, terdiri dari beberapa komponen energi seperti bond enegry, valence angle, torsion angle, lone pair electron, Van der Walls dan Colomb.

$$
\begin{aligned}
E_{\text {sys }}= & E_{\text {bond }}+E_{\text {over }}+E_{\text {under }}+E_{l p}+E_{\text {val }} \\
& +E_{\text {pen }}+E_{\text {tor }}+E_{\text {conj }}+E_{\text {VndWalls }}+E_{\text {colomi }}
\end{aligned}
$$

Komponen $E_{\text {bond }}$ merupakan fungsi dari Bond Order (BO). Sedangkan Bond Order merupakan fungsi jarak antar atom sesaat sehingga bisa memperlihatkan dinamika pembentukan dan pemutusan ikatan antar atom.

Keakuratan dan kinerja dari Fungsi potensial (force field) ini telah teruji dan telah digunakan oleh salah seorang dari penulis untuk simulasi proses oksidasi basah silikon, yaitu dengan molekul air [18]. Kotak simulasi menerapkan syarat batas campuran (mixed boundary condition) dengan syarat batas periodik (periodic boundary condition) pada sumbu-X dan sumbu-Y, dan syarat batas tetap (Isolated/Fixed boundary condition) pada sumbu-Z dengan ukuran boks $38,4 \AA, 38,4 \AA$ dan $76,0 \AA$ secara berurutan. Struktur awal 
sistem diinisialisasi sebagai struktur silikon kristal diamond dengan lattice constant 5,4307 ̊.

Atom-atom Si dibagi menjadi tiga lapisan seperti yang ditunjukkan oleh Gambar 1. Lapisan warna merah merupakan atom-atom $\mathrm{Si}$ yang tidak terpengaruh oleh perlakuan yang diterapkan pada sistem (fixed layer), dengan tujuan untuk menirukan kondisi riil.

Proses amorfisasi dilakukan dengan metode melt-quench yaitu dengan memanaskan struktur kristal silikon hingga mencapai titik leburnya (melting) kemudian melakukan pendingan (quenching) dengan laju pendinginan (cooling rate) yang tinggi (1012-1015K/s) hingga mencapai suhu ruangan. Proses pemanasan (melting) dilakukan dengan menerapkan velocity rescaling hingga sistem mencapai suhu $3500 \mathrm{~K}$, kemudian melakukan proses pendinginan dengan menerapkan ensembel NVT dengan laju pendinginan $1014 \mathrm{~K} / \mathrm{s}$ hingga mencapai suhu $300 \mathrm{~K}$.

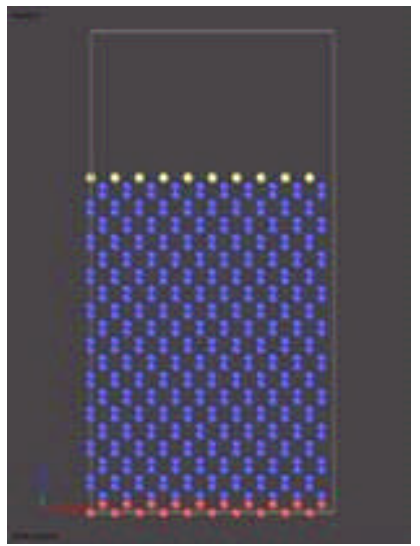

Gambar 1. Kondisi awal sistem: struktur silikon kristal diamond

\section{HASIL DAN PEMBAHASAN}

\section{Pembahasan Amorfisasi Silikon}

Proses amorfisasi pada penelitian ini dapat dibagi menjadi dua tahap, yaitu proses pemanasan (melting) pada struktur silikon kristal hingga diperoleh silikon pada fase cair atau silikon cair dan dilakukan proses pendinginan secara cepat (quenching) untuk memperoleh struktur silikon amorf.

\section{Proses Pemanasan (Melting)}

Suhu sistem ditingkatkan hingga 3500K dengan melakukan velocity-rescaling (mengubah-ubah kecepatan untuk mengatur suhu) kemudian membiarkan sistem mengalami proses ekuilibrasi dengan menerapkan ensembel NVT untuk menjaga suhu sistem konstan pada $3500 \mathrm{~K}$. Alasan pemilihan suhu melting $3500 \mathrm{~K}$ berdasarkan simulasi yang pernah dilakukan pada suhu 2500K, 3000K, 3700K dan 4000K. Hasil simulasi yang dilakukan pada suhu di bawah $3500 \mathrm{~K}$ tidak berhasil menunjukkan sistem yang berada pada fase cair, sedangkan hasil simulasi yang dilakukan pada suhu di atas $4000 \mathrm{~K}$ menunjukkan bahwa sistem berada pada fase terjadinya proses penguapan.

\section{Fungsi Distribusi Radial Radial Distribution Function (RDF) dan Karakteristik Ikatan}

Fungsi Distribusi Radial g(r) menggambarkan bagaimana kerapatan berubah sebagai fungsi jarak dari partikel yang jadi acuan seperti pada Persamaan (1).

$$
g(r)=4 \pi r^{2} \rho d r
$$

Gambar 2. menunjukkan grafik $R D F$ struktur silikon amorf hasil proses melting-quenching.

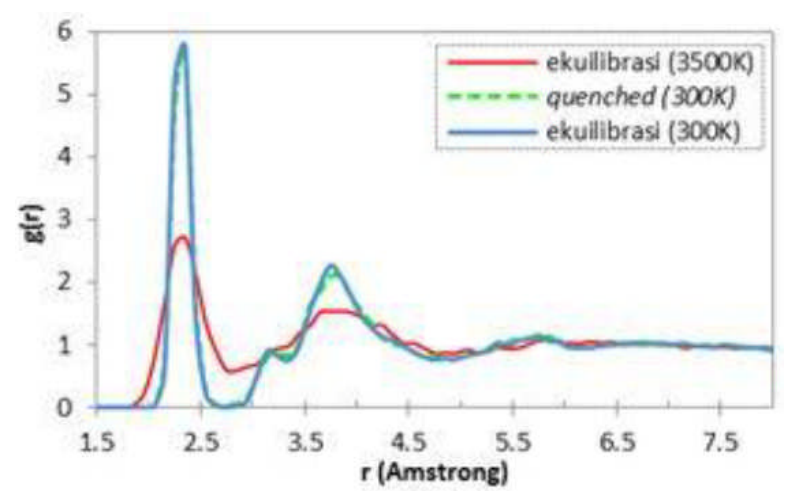

Gambar 2. Grafik $R D F$ struktur silikon amorf hasil proses quenching.

Kurva warna hijau dan biru merupakan grafik $R D F$ sistem pada suhu $300 \mathrm{~K}$. Tidak terdapat perbedaan kurva yang cukup signifikan pada grafik $R D F$ di antara sistem pada suhu $300 \mathrm{~K}$ sebelum dan sesudah dilakukan proses ekuilibrasi.

Byeong June Min [12] melakukan simulasi MD amorfisasi silikon dengan menerapkan tiga konfigurasi proses pendinginan (quenching) silikon cair yang berbeda yaitu "fast-quenched" dengan cooling rate $10^{14} \mathrm{~K} / \mathrm{s}$, "slow-quenched" dengan laju pendinginan (cooling rate) $\sim 10^{13}$ dan $\sim 10^{12} \mathrm{~K} / \mathrm{s}$, dan "annealing" yaitu kombinasi antara "fast-quenched" dan proses anil yang dilakukan pada suhu 900K. Simulasi yang dilakukan oleh Byeong June Min menggunakan model interaksi atom silikon dengan fungsi potensial Evironment-Dependent Empirical Tight-Binding. Grafik $R D F$ yang diperoleh dari simulasi yang dilakukan Min diberikan pada Gambar 3.

Tabel 1 merupakan hasil karakteristik ikatan pada silikon amorf dengan potensial ReaxFF dan hasil simulasi lain serta hasil pengukuran secara eksperimen. $C_{n}$ adalah fraksi ikatan $n$-fold dan $C_{N}$ adalah ikatan rata-rata (coordination number).

Tidak terdapat perbedaan kurva yang signifikan dari ketiga konfigurasi proses quenching yang dilakukan oleh Byeong June Min (Gambar 3), namun dari hasil analisis yang dilakukan oleh Byeong June Min, ketiga 


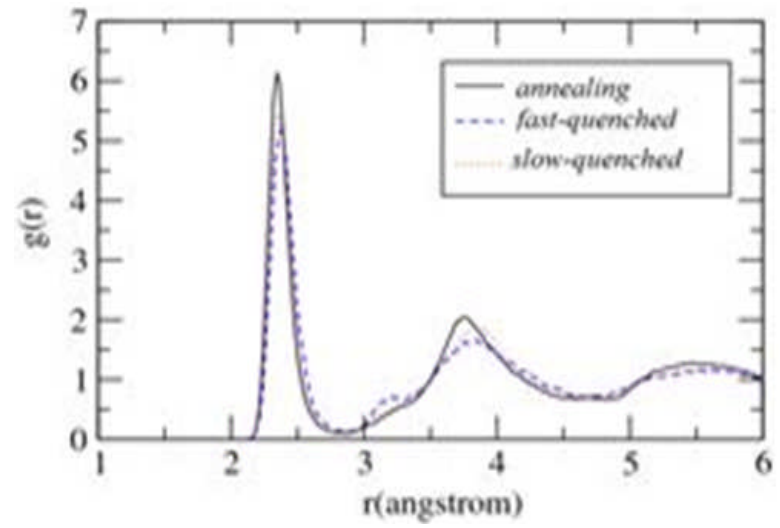

Gambar 3. Grafik RDF silikon amorf oleh Min (2010) dengan tiga konfigurasi proses quenching yang berbeda.

Tabel 1. Hasil karakteristik ikatan pada silikon amorf dengan potensial ReaxFF dan hasil simulasi lain serta hasil pengukuran secara eksperimen. $\mathrm{Cn}$ adalah fraksi ikatan $\mathrm{n}$-fold dan $\mathrm{CN}$ adalah ikatan rata-rata (coordination number).

\begin{tabular}{llllll}
\hline Fungsi Potensial & $C_{3}(\%)$ & $C_{4}(\%)$ & $C_{5}(\%)$ & $C_{5}(\%)$ & $C_{N}$ \\
\hline $\begin{array}{l}\text { ReaxFF } \\
\quad \text { Hasil penelitian }\end{array}$ & & & & & \\
$\quad$ ini) & & & & & \\
$\quad 300 \mathrm{~K}$ (annealed) & 1,74 & 86,80 & 11,46 & - & 4,10 \\
$\quad 300 \mathrm{~K}$ & & & & & \\
$\quad$ (equilibrated) & 0,65 & 89,25 & 10,05 & 0,04 & 4,09 \\
Tersoff [15] & & & & & \\
$\quad$ equilibrated & & & & - & $3,58-3,74$ \\
EDETB [12] & & & & & \\
$\quad$ quenched & & & & & \\
$\quad$ annealed & & & & & \\
Eksperimen[19] & & & & & \\
$\quad$ Quenched & & & & & 3,55 \\
$\quad$ Annealed & & & & & 3,90 \\
$\quad$ Equilibrated & & & & & \\
\hline
\end{tabular}

konfigurasi quenching tersebut menghasilkan struktur silikon amorf dengan karakteristik coordination number (jumlah tetangga terdekat) yang berbeda (Tabel 1). Kasus serupa ditemui pada hasil proses quenching dalam penelitian ini, di mana dari kedua kurva grafik $R D F$ Gambar 2 yang relatif sama (kurva $R D F$ sebelum dan sesudah dilakukan proses ekuilibrasi), memiliki karakteristik coordination number yang berbeda.

Karakteristik coordination number yang diperoleh dari hasil simulasi ini serta hasil dari beberapa penelitian lain sebagai data pembanding diberikan oleh Tabel 1. [12,15,19]. Berdasarkan Tabel 1 yang terjadi pada struktur silikon amorf hasil Dinamika Molekuler yang kami lakukan, coordination defect (cacat ikatan) dapat dibagi menjadi dua tipe yaitu terbentuknya ikatan 3-fold (dangling bonds, DB) dan ikatan 5-fold (floating bonds, $F B)$. Hal ini tidak teramati pada dinamika molekuler dengan potensial Tersoff sehingga rata coordination number yang dilaporkan Treacy et.al [15] kurang dari 4 sedangkan menurut penelitian ini sedikit lebih dari 4 .

Ishimaru [13] melakukan analisis terhadap distribusi spasial dari defect (ikatan 'cacat') dengan fungsi distribusi radial parsial $\mathrm{g}_{\mathrm{ij}}(\mathrm{r})$ untuk masing-masing

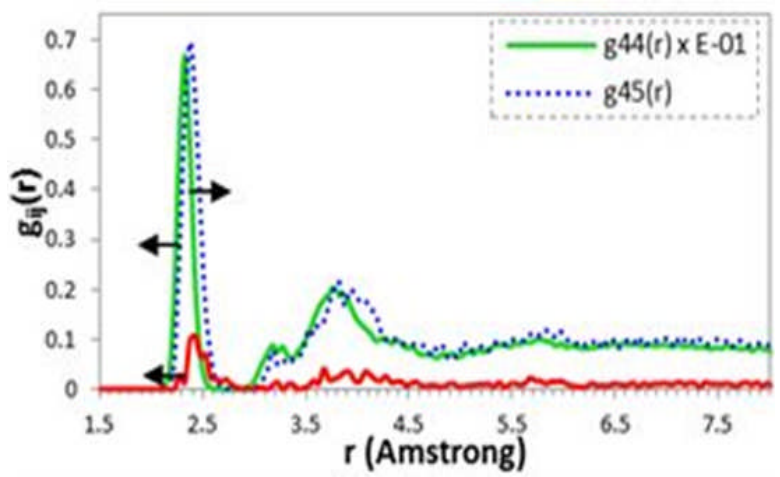

Gambar 4. Fungsi distribusi radial parsial gij(r) yang merepresentasikan probabilitas atom dengan ikatan $i$-foldper satuan unit volume untuk menemukan atom dengan ikatan $j$-fold pada jarak $\mathrm{r}$.

jenis ikatan pada silikon amorf. Hasil analisis terhadap fungsi distribusi radial parsial struktur silikon amorf yang diperoleh dari penelitian ini diberikan oleh Gambar 4 Panjang rata-rata ikatan (letak puncak pertama) cenderung bertambah pada ikatan 4-4 fold, 4-5 fold dan 5-5 fold secara berurutan. Karakteristik tersebut sesuai dengan hasil analisis yang dilakukan oleh Ishimaru, seperti pada Persamaan (2).

$$
\text { Rasio } \int_{0}^{r m} g_{55}(r) d r / \int_{0}^{r m} g_{45}(r) d r=0.172
$$

$\mathrm{r}_{\mathrm{m}}$ merupakan harga minimum pertama pada grafik $\mathrm{g}_{\mathrm{ij}}(\mathrm{r})$, lebih besar dibanding rasio jumlah atom ikatan 5-fold dan jumlah ikatan 4-fold, $\mathrm{N}_{5} / \mathrm{N}_{4}=0,112$ merepresentasikan bahwa atom ikatan 5-fold relatif cenderung untuk berikatan dengan atom ikatan 5-fold lainnya dibanding dengan atom ikatan 4-fold. Hasil analisis tersebut dapat diamati pada Gambar 5 (b) yang menunjukkan persebaran atom-atom silikon dengan ikatan 5-fold.
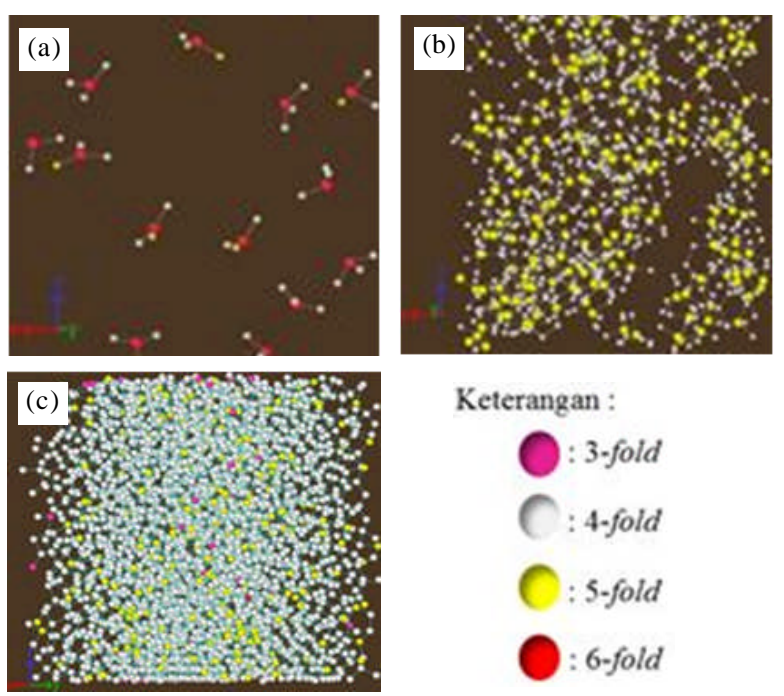

Gambar 5. Visualisasi struktur sistem (a). distribusi atom dengan ikatan 3-fold, (b). distribusi atom dengan ikatan 5-fold, dan (c) silikon amorf 


\section{Fungsi Distribusi Sudut-Ikatan}

Sudut-ikatan rata-rata berdasarkan fungsi distribusi sudut-ikatan yang ditunjukkan oleh Gambar 6 adalah $\theta=108,3^{\circ}$ dengan standar deviasi $\delta \theta=11,36^{\circ}$. Hasil tersebut sesuai dengan hasil pengukuran eksperimen menggunakan difraksi neutron yang melaporkan bahwa puncak grafik distribusi sudut-ikatan mendekati sudut tetrahedral $\left(108,6^{\circ}\right)$ dengan deviasi $\delta \theta=0,2^{\circ}[20]$.

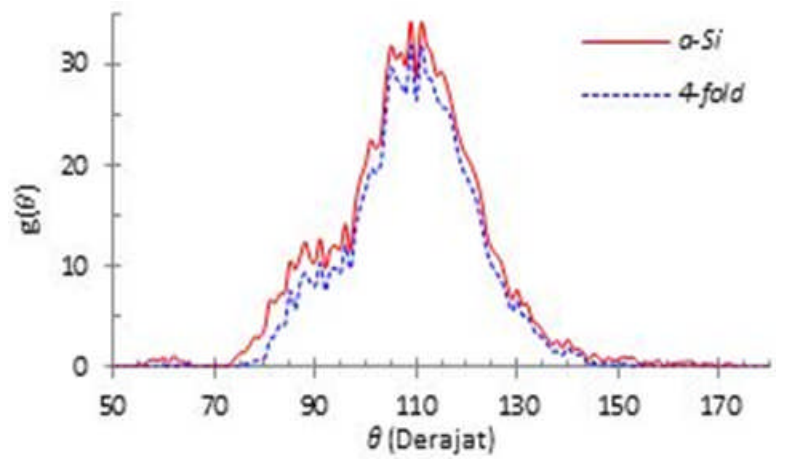

Gambar 6. Grafik distribusi sudut-ikatan silikon amorf (keterangan : sumbu-y berdasarkan fraksi sudut-ikatan terhadap jumlah total sudut-ikatan sistem, range data pada sumbu-y sebesar 1)
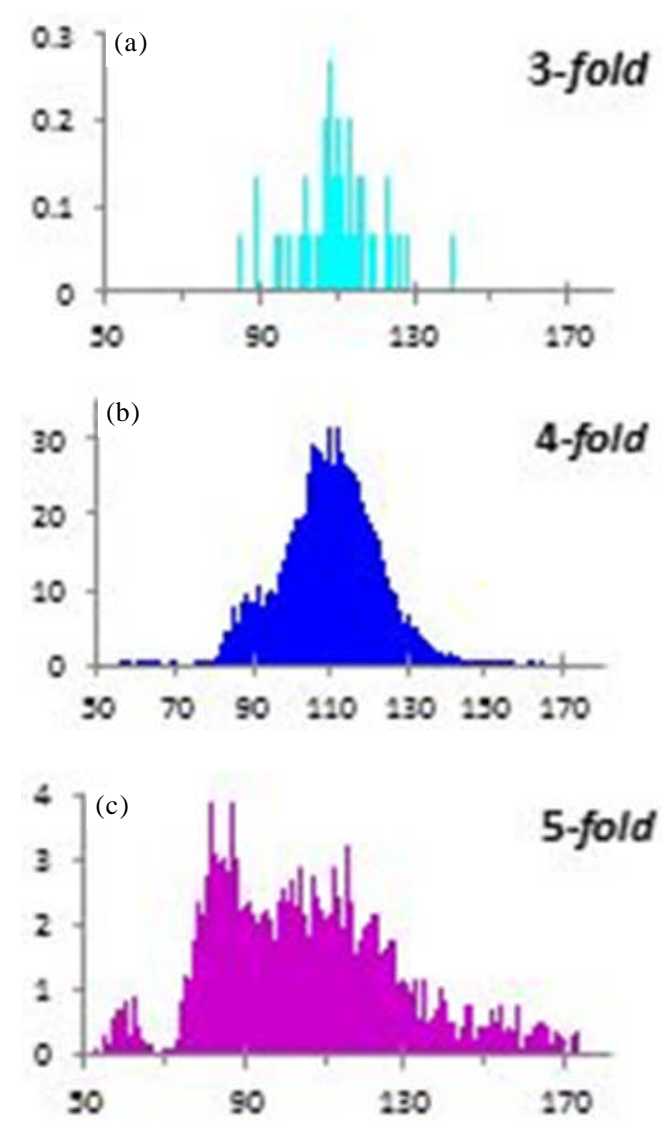

Gambar 7. Grafik fungsi distribusi sudut-ikatan silikon amorf (a), (b), dan (c) distribusi sudut-ikatan untuk ikatan 3-fold, 4-fold dan 5-fold secara berurutan (keterangan : sumbu-x berdasarkan fraksi sudut-ikatan terhadap jumlah total sudut-ikatan sistem, range data pada sumbu-x adalah 1)
Grafik fungsi distribusi sudut-ikatan struktur silikon amorf (Gambar 6) menunjukan iregularitas pada sudut $\sim 60^{\circ}$ dan $\sim 90^{\circ}$. Berdasarkan pada Gambar 7 (c) puncak yang teramati pada sudut $\sim 60^{\circ}$ tersebut merupakan hasil kontribusi dari fungsi distribusi sudutikatan oleh ikatan 5-fold. Kontribusi sudut-ikatan oleh ikatan 3-fold tidak terlalu signifikan karena memiliki fraksi yang rendah berdasarkan Tabel 1. Secara statistik distribusi sudut-ikatan rata-rata pada ikatan 4-fold adalah $\sim 110^{\circ}$ (sudut ikatan tetrahedral) meskipun terdapat iregularitas pada sudut $\sim 90^{\circ}$ (Gambar 7 (b)). Ikatan 5-fold memiliki distribusi sudut ikatan yang relatif tersebar merata dengan puncak yang terletak pada sudut $\sim 60^{\circ}$ dan $\sim 90^{\circ}$.

Secara statistik konfigurasi ikatan 5-fold dapat dikategorikan ke dalam dua bentuk umum seperti yang ditunjukkan pada Gambar 8 (b) dan (c). Bentuk konfigurasi ikatan dengan ikatan 3-ring pada Gambar 8 (b) menghasilkan sudut ikatan dengan sudut $60^{\circ}$,
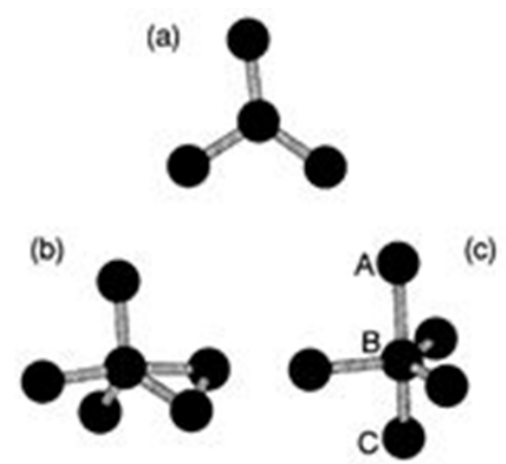

Gambar 8. Model geometris konfigurasi ikatan (a). dangling bond dan (b), (c) floating bond (Ishimaru, 2001).
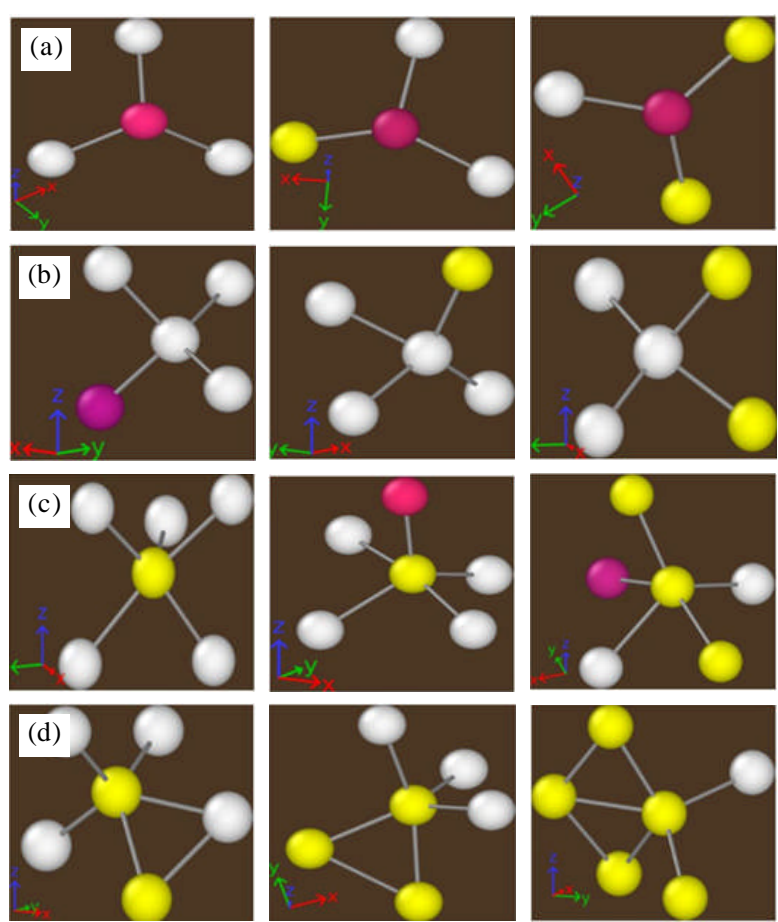

Gambar 9. Visualisasi struktur Silikon amorf (a), (b), (c) dan (d) distribusi ikatan 3-fold, 4-fold, 5-fold dan 6-fold. 
sedangkan sudut ikatan $\sim 90^{\circ}$ diperoleh dari konfigurasi ikatan A-B-C pada Gambar 8 (c). Gambar 9 menunjukkan model atom-atom dengan konfigurasi 3-fold, 4-fold dan 5-fold.

\section{KESIMPULAN}

Silikon amorf terbentuk dengan pemanasan sampai $3500 \mathrm{~K}$ yang diikuti dengan pendinginan ke suhu kamar dengan laju pendinginan 1014K/s. Panjang rata-rata ikatan (letak puncak pertama) cenderung bertambah pada ikatan 4-4 fold, 4-5 fold, dan 5-5 fold secara berurutan. Distribusi sudut-ikatan oleh ikatan 5-fold memiliki kontribusi yang signifikan terhadap terbentuknya puncak sudut 60 . Selama proses ekuilibrasi, struktur sistem mengalami disorder atau proses peningkatan keacakan struktur cenderung bertambah pada ikatan 4-4 fold, 4-5 fold, dan 5-5 fold secara berurutan.

\section{DAFTAR ACUAN}

[1]. H. Tanimoto, H. Arai, H. Mizubayashi, M. Yamanaka, and I. Sakata. "Light-Induced Hydrogen Evolution from Hydrogenated Amorphous Silicon: Hydrogen Diffusion by Formation of Bond Centered Hydrogen.” J. Appl. Phys., vol. 115, no. 7, 2014.

[2]. K. Jäger, D. N. P. Linssen, O. Isabella, and M. Zeman. "Ambiguities in Optical Simulations of Nanotextured Thin-Film Solar Cells Using The Finite-Element Method." Opt. Express, vol. 23, no. 19,pp. A1060, 2015.

[3]. P. Biswas, D. A. Drabold, R. Atta-fynn, P. Biswas, D. A. Drabold, and R. Atta-fynn. "Microstructure From Joint Analysis Of Experimental Data and $\mathrm{Ab}$ Initio Interactions: Hydrogenated Amorphous Silicon.” J. Appl. Phys., vol. 116, no. 24, p. 244305, 2014.

[4]. E. M. El Mhamdi, J. Holovsky, B. Demaurex, C. Ballif, and S. De Wolf. "Is light-induced Degradation of a-Si:H/OSi Interfaces Reversible." Appl. Phys. Lett., vol. 104, no. 25, 2014.

[5]. A.-M. El-Sayed, M. B. Watkins, T. Grasser, V. V. Afanas'ev, and A. L. Shluger. "Hydrogen-Induced Rupture of Strained Si\%O Bonds in Amorphous Silicon Dioxide.” Phys. Rev. Lett., vol. 114, no. 11, pp. 1-5, 2015.

[6]. I. Sakata, T. Kamei, and M. Yamanaka, "Lightinduced Annealing of Hole Trap States: A New Aspect of Light-Induced Changes in Hydrogenated Amorphous Silicon," J. Non. Cryst. Solids, vol. 358, no. 17, pp. 2048-2051, Sep. 2012.

[7]. M. A. Pamungkas and R. Widiyatmoko. "Effect of Hydrogenation Temperature on Distribution of Hydrogen Atoms in c-Si and a-Si/ : Molecular Dynamic Simulations.” Key Eng. Mater., vol. 706, pp. 55-59, 2016.
[8]. T. Matsui, A. Bidiville, K. Maejima, H. Sai, T. Koida, T. Suezaki, M. Matsumoto, K. Saito, I. Yoshida, and M. Kondo. "High-Efficiency Amorphous Silicon Solar Cells: Impact of Deposition Rate on Metastability.” Appl. Phys. Lett., vol. 106, no. 5, 2015.

[9]. E. Johlin, L. K. Wagner, T. Buonassisi, and J. C. Grossman. "Origins of Structural Hole Traps in Hydrogenated Amorphous Silicon." Phys. Rev. Lett., vol. 110, no. 14, pp. 146805, Apr. 2013.

[10]. C. Freysoldt, G. Pfanner, and J. Neugebauer. "The Dangling-Bond Defect in Amorphous Silicon: Statistical Random Versus Kinetically Driven Defect Geometries." J. Non. Cryst. Solids, vol. 358, no. 17, pp. 2063-2066, Sep. 2012.

[11]. M. Fehr, a. Schnegg, B. Rech, K. Lips, O. Astakhov, F. Finger, C. Freysoldt, R. Bittl, and C. Teutloff. "Dangling Bonds in Amorphous Silicon Investigated by Multifrequency EPR.” J. Non. Cryst. Solids, vol. 358, no. 17, pp. 2067-2070. 2012.

[12]. J. M. Byeong. "Environment-dependent Empirical Tight-binding Molecular Dynamics Study of Amorphous Silicon.” J. Korean Phys. Soc., vol. 56, no. 5, p. 1500, 2010.

[13]. M. Ishimaru, "Molecular-dynamics Study on Atomistic Structures of Amorphous Silicon." J.Phys Condens. Matter, vol. 13, p. 4181, 2001.

[14]. J. M. Larkin and A. J. H. McGaughey. "Thermal Conductivity Accumulation in Amorphous Silica and Amorphous Silicon.” Phys. Rev. B - Condens. Matter Mater. Phys., vol. 89, no. 14, pp. 1-12, 2014.

[15]. M. M. J. Treacy and K. B. Borisenko. "The Local Structure of Amorphous Silicon.” Science (80-. )., vol. 335, no. 6071, pp. 950-953, 2012.

[16]. T. P. Senftle, S. Hong, M. M. Islam, S. B. Kylasa, Y. Zheng, Y. K. Shin, C. Junkermeier, R. Engel-Herbert, M. J. Janik, H. M. Aktulga, T. Verstraelen, A. Grama, and A. C. T. van Duin. "The ReaxFF Reactive Force-Field: Development, Applications and Future Directions." Comput. Mater., vol. 2, pp. 15011, 2016.

[17]. A. Dequidt, J. Devémy, and A. A. H. Pádua.'Thermalized Drude Oscillators with the LAMMPS Molecular Dynamics Simulato." J. Chem. Inf. Model., vol. 56, no. 1, pp. 260-268, 2016.

[18]. M. A. Pamungkas, B.-H. Kim, and K.-R. Lee. "Reactive molecular dynamic simulations of early stage of wet oxidation of Si (001) surface.” J. Appl. Phys., vol. 114, no. 7, pp. 73506, 2013.

[19]. A. Filipponi, F. Evangelisti, M. Benfatto, S. Mobilio, and C. R. Natoli. "Structural investigation of a-Si and a-Si:H using x-ray-absorption spectroscopy at the Si K edge." Phys. Rev. B, vol. 40, no. 14, pp. 9636-9643, 1989.

[20]. J. Fortner and J. S. Lannin. "Radial distribution functions of amorphous silicon." Phys. Rev. B, vol. 39, no. 8, pp. 5527-5530, 1989. 